\title{
Dengue hemorrhagic fever vulnerability assessment in Gorontalo Regency using analytic hierarchy process and geoinformation techniques
}

\author{
Ririn Pakaya ${ }^{1}$, Yanti Hz. Hano ${ }^{1}$, Muhammad Ramdhan Olii $^{2}$ \\ ${ }^{1}$ Department of Public Health, Public Health Faculty, Universitas Gorontalo, Gorontalo, Indonesia \\ ${ }^{2}$ Department of Civil Engineering, Engineering Faculty, Universitas Gorontalo, Gorontalo, Indonesia
}

\begin{tabular}{l} 
Article Info \\
\hline Article history: \\
Received Jun 28, 2021 \\
Revised Nov 5, 2021 \\
Accepted Nov 19, 2021 \\
\hline Keywords: \\
AHP \\
DHF \\
GIS \\
Spatial analysis \\
Surveillance strategies \\
Vulnerability
\end{tabular}

\begin{abstract}
One method of reducing the spread of dengue hemorrhagic fever (DHF) is to provide a map of DHF-prone locations based on spatial analysis. The major way to prevent the spread of DHF is to manage and control its vector by focussing on specific regions of localisation and removing appropriate breeding circumstances. Spatial analysis can detect DHF clusters that are larger than expected based on the underlying data. This research aimed to identify and map DHF vulnerability zones based on many parameters within the scope of the analytical hierarchy and geographical information systems (GIS). We found that the consistency ratio of 0.079 for analytic hierarchy process (AHP) factor weights was judged to be satisfactory. The population density, distance to the road, and distance to health facilities were shown to be the most relevant factors in determining DHF vulnerability. Gorontalo Regency is dominated by low vulnerability classes with an area of 139,493.5 ha or $65.08 \%$ of the total area. The GIS-AHP process could be used to assess transmissible DHF vulnerability zonation, which would aid in improving surveillance strategies for DHF and other vector-borne diseases in order to encourage prevention and control actions.
\end{abstract}

This is an open access article under the CC BY-SA license.

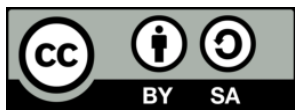

\section{Corresponding Author:}

Ririn Pakaya

Department of Public Health, Public Health Faculty, Universitas Gorontalo

Jalan A.A. Wahab No. 247, Limboto, Gorontalo, Indonesia

Email: ririn.pakaya@mail.ugm.ac.id

\section{INTRODUCTION}

Dengue hemorrhagic fever (DHF) is a viral infection spread by mosquitos that has spread fast across all world health organization (WHO) areas in recent years, particularly in tropical and subtropical climates. [1]. Dengue virus is transmitted to people via female mosquito bites, predominantly Aedes aegypti and to a lesser extent, Aedes albopictus. Additionally, these mosquitoes spread the chikungunya, yellow fever, and Zika viruses. DHF is widespread across the tropics, with risk levels varying according to factors such as rainfall, temperature, relative humidity, and unplanned rapid urbanisation.

DHF has been increasingly prevalent throughout the world in recent decades. Due to the fact that the vast majority of DHF cases is asymptomatic or mild and can be self-managed, the true number of DHF is almost certainly underestimated. Additionally, a significant proportion of cases are misdiagnosed as other febrile disorders [2]. Each year, 390 million dengue virus infections are estimated to occur (95\% credible interval: 284-528 million), with 96 million (67-136 million) presenting clinically (with any severity of disease) [3]. According to another study on the prevalence of dengue, 3.9 billion people are at risk of infection with dengue viruses. Despite the fact that there is a risk of infection in 129 countries [4] Asia bears 
$70 \%$ of the actual burden [3]. Since 2000, the number of DHF cases reported to the WHO has increased by more than eightfold, from 505,430 cases in 2000 to more than 5.2 million cases in 2019. According to reports of WHO, the number of reported deaths climbed from 960 in 2000 to 4032 in 2015. This year's dengue fever outbreaks have spread to various nations, with an uptick in cases reported in countries such as Indonesia, India, Maldives, Mauritania, Mayotte (France), Bangladesh, Brazil, Nepal, Singapore, Sri Lanka, Sudan, Thailand, Timor-Leste, Cook Islands, Ecuador, and Yemen. DHF will continue to strike Brazil, the Cook Islands, Colombia, Fiji, Kenya, Paraguay, Peru, and Reunion Island in 2021.

The geographical information systems (GIS) for health applications is quickly becoming one of the most essential tools for detecting spatial correlations, and it is being utilised by an increasing number of researchers throughout the world [1], [5]-[12]. In dealing with the DHF disaster that occurs, it can not only be solved with preventive measures such as draining, closing and burying, which has been carried out and socialized by governments, but also requires mitigation actions. One way to reduce the spread of DHF is to provide a map of locations that are prone to DHF by spatial analysis. Preventing the spread of DHF is mostly accomplished by controlling its vector by concentrating on specific localised regions and removing breeding circumstances that are conducive to its reproduction [13]. Spatial analysis can identify DHF clusters that are larger than what would be expected based on the underlying environmental characteristics, climatology, and demographic structure. The integration of the analytical hierarchy process (AHP) method in GIS to solve public health concerns has gotten a lot of interest from researchers [8], [9], [12], [14]. Multi-criteria decision making techniques can be utilised to make the public health challenges more plain, logical, and efficient.

According to Bhatt and Joshi [12], integrating geospatial technologies and AHP for malaria risk zones and transmission dynamics has significant implications and possible benefits. Dom et al. [13] reported that the findings of their study provided valuable insights that could be used to improve public health initiatives in the future. GIS and spatial analytical methods could be used to supplement DHF and other communicable disease surveillance strategies in order to promote prevention and control actions. Using AHP-GIS, Ali and Ahmad [8] illustrated how it may be used to better understand the structure and distribution of dengue outbreaks, as well as the zonation of prospective dengue outbreak risk regions. Rakotoarison et al. [14] proved GIS integrated with AHP, with their capacity for spatially referenced data storage, data management, analysis, modeling, and mapping, is a useful tool for understanding spatial decision issues in malaria-risk areas in Madagascar. Li et al. [15] evaluated the risk of Zika disease transmission in Guangdong, China, and discovered that the risk was higher in the Pearl River Delta, which included Guangzhou, Shenzhen, and Nanjing.

Previous studies used GIS-AHP to simulate DHF risk or vulnerability, with variables such as topography, climatology, and population demography being used to construct the models. There are limitations to these variables, and as a result, this study recommends the use of various variables that allow contact between people, specifically the transmission of DHF from infected female mosquitoes to humans through their bites. (i.e. population density, distance to the road, radius of health facilities, radius of educational facilities, radius of office area, and land use) to define DHF vulnerability zones. It was decided to use a buffer distance because of the flight distance factors that were covered during the Aedes mosquito's life span [16]. Female mosquitoes have an average lifespan of 8-15 days and can fly 30-50 meters per day. This suggests that female mosquitos can travel a distance of 240-600 m during their lifetime [17].

\section{RESEARCH METHOD}

\subsection{Study area}

Gorontalo District is a plateau with an average elevation of 50 meters above sea level and an altitude range of 0 to 2,062 meters. Gorontalo District is geographically located between $0^{\circ} 28^{\prime} 23.22^{\prime \prime}-0^{\circ} 55^{\prime} 45.08^{\prime \prime}$ North Latitude and $122^{\circ} 14^{\prime} 43.69^{\prime \prime}-123^{\circ} 4{ }^{\prime} 48.27^{\prime \prime}$ East Longitude (Figure 1). Gorontalo Regency has a total land area of $2,159 \mathrm{~km}^{2}$. The administrative area of Gorontalo Regency in 2020 consists of 19 Districts and 205 villages, with Limboto District serving as the capital city. The largest district is Asparaga District, which covers $430.51 \mathrm{~km}^{2}$ or $20.25 \%$ of the land area in Gorontalo Regency, Indonesia while the smallest subdistrict is Tilango District, which covers $5.79 \mathrm{~km}^{2}$ or $0.27 \%$ of the total area in Gorontalo Regency. North Gorontalo Regency borders the northern part of Gorontalo Regency, Bone Bolango Regency, and Gorontalo City border the eastern part, Tomini Bay borders the southern part, and Boalemo Regency borders the western part. The highest temperature in Gorontalo Regency in 2020 was $35.2^{\circ} \mathrm{C}$ in October, while the lowest temperature was $18.8^{\circ} \mathrm{C}$ in September. In March and June, the humidity reaches $97 \%$, while in October, the humidity drops to $65 \%$. The highest duration of exposure was in September, at $79.90 \%$, and the lowest was $45.10 \%$. The wettest month is December, with 27 rainy days. 


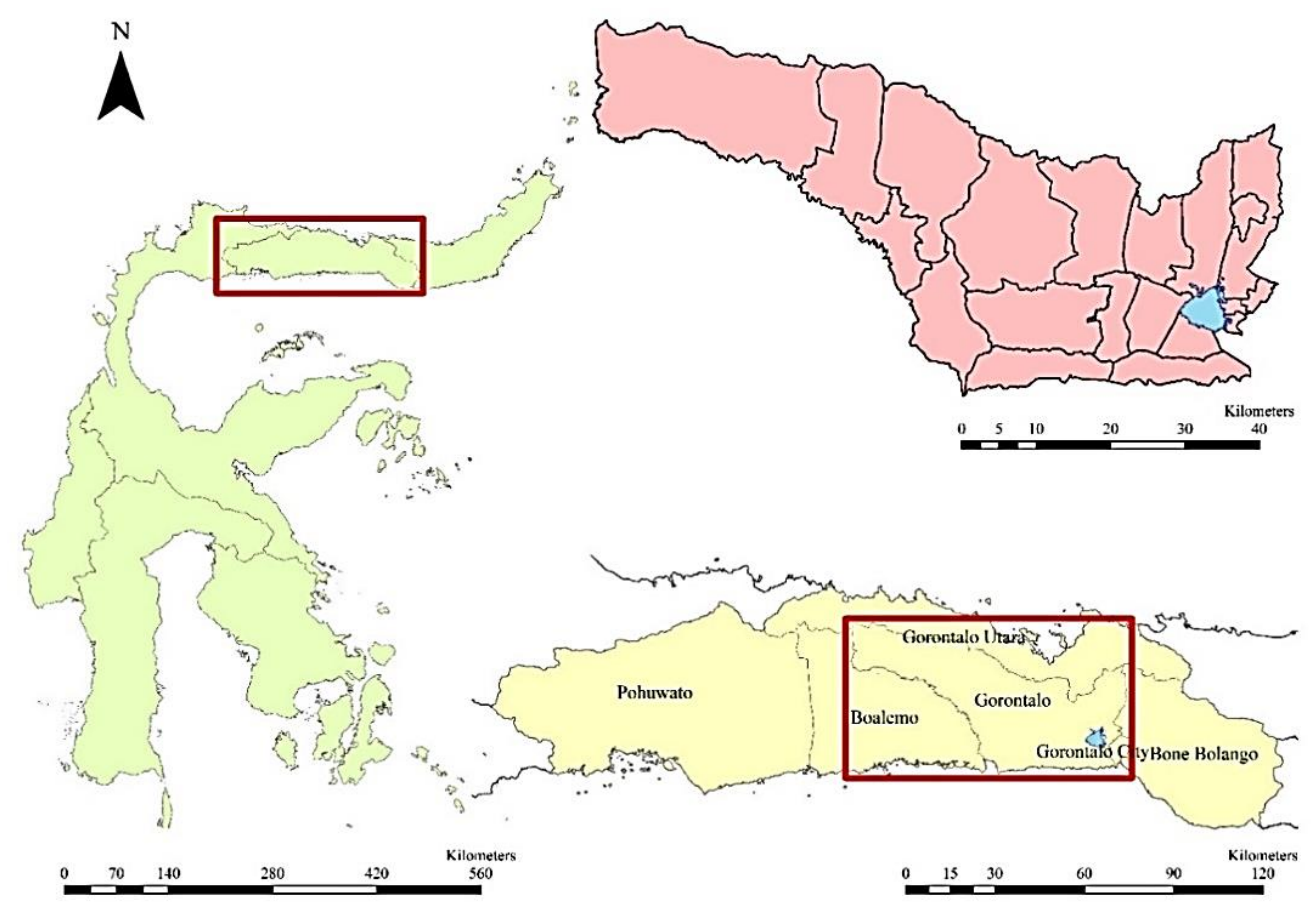

Figure 1. Location of the study area

\subsection{Determination of preliminary list of factor}

It is necessary to evaluate the DHF vulnerability factors and their relationship to the DHF cases in question. Prepared and constructed a spatial database containing DHF factors in order to conduct a vulnerability analysis of the system. The factors that are considered vary from one study area to another, and this is due to the fact that each location has its own unique characteristics. There is no exact agreement on which factors should be used in DHF vulnerability assessments. However, some of the variables are commonly used by many researchers, indicating their importance in DHF vulnerability. This set of variables was selected for the current study based on the results of a field survey and information gathered from the literature. In the DHF vulnerability mapping process, a total of six factors were considered: population density, distance to the road, radius of health facilities, radius of educational facilities, radius of office area, and land use. Each factor was converted into a $50 \times 50 \mathrm{~m}$ grid spatial database, and the grid of the Gorontalo Regency was built with 857,280 grids (214,341.9 ha).

Rural areas are likely to contribute at least as much to the spread of DHF as urban areas, according to recent research [18]. Intervening in areas where there is a high human population density, which is critical for DHF transmission, could improve the efficiency of vector control, especially because population density figures are relatively easy to obtain [18]. In this study population density was divided into three classes i.e. $>1,000$ person $/ \mathrm{km}^{2} ; 500-1,000$ person $/ \mathrm{km}^{2}$; and $<500$ person $/ \mathrm{km}^{2}$ (Figure 2). The correlation between DHF cases and population density was DHF cases (r) is 0.891 , while the Sig. (2-tailed) $<0.05$, so the incidence of DHF cases is significant [19].

The public facilities (i.e. school, road, and office) cause mosquito breeding sites to increase and human interaction to increase. A study conducted on the University of Malaya campus in Kuala Lumpur by Chen et al. [20] found that $50 \%$ of all natural containers surveyed were positive for mosquito larvae, followed by plastic containers (32.77\%), plastic pails (23.81\%), concrete tanks $(20 \%)$, vases $(18.7 \%)$, and other containers (11.90\%). Aside from the elimination of artificial and natural containers, it is also necessary to consider the modification of breeding sites in and around public facilities in order to control the spread of these mosquitoes [20]. Mahabir et al. [21] reported that there is a link between the incidence of dengue and the presence of roads. Because of the high volume of traffic on major highways, especially during mosquito blood feeding periods (early morning and late evening), which coincide with commuters' journeys to and from work, major highways may act as major "barriers" to flying mosquitoes. During this time of day, the foraging mosquitoes' flight speed allows them to become victims of the travelling velocity of vehicles. Aside from that, the width of major roads increases the chances of being caught in a vehicle's "wind tunnel." Minor 
highways, on the other hand, are typically narrower in width and have a lower volume of traffic than major highways. Generally, the findings show an increase in the number of DHF cases occurring closer to minor class roads, which is consistent with previous research [21]. Regilme et al. [22] argued that human-made landscape features such as primary highways could act as barriers to mosquito travel, reducing gene flow over the road. Harapan et al. [23] stated DHF cases correlate by health facilities. First, to begin, this drop was attributed to improved disease management methods at Community Health Centers and hospitals. Second, this was connected with increasing community and provider knowledge and awareness, as well as improved diagnoses, including more sensitive and specific diagnostic tests [23]

Complex interactions between vector, host, and virus drive DHF transmission. Land use, such as water bodies or specialised agricultural techniques, has been recognised as a potential risk factor for DHF due to the vector's habitat [24]. Land use characteristics are a key component in strategic planning and implementation of vector control [24]. In this study, land use devide into water bodies (2,808 ha), settlement (2,926 ha), plantation/agriculture (71,790), shrubs/open Area (52,307 ha), and forest (84,511 ha) (Figure 2). The incidence rate of dengue in the high vegetation areas was low (cases per 100,000 population), but high in the low-vegetation areas with a surface temperature of $29 \pm 2{ }^{\circ} \mathrm{C}$ [25].
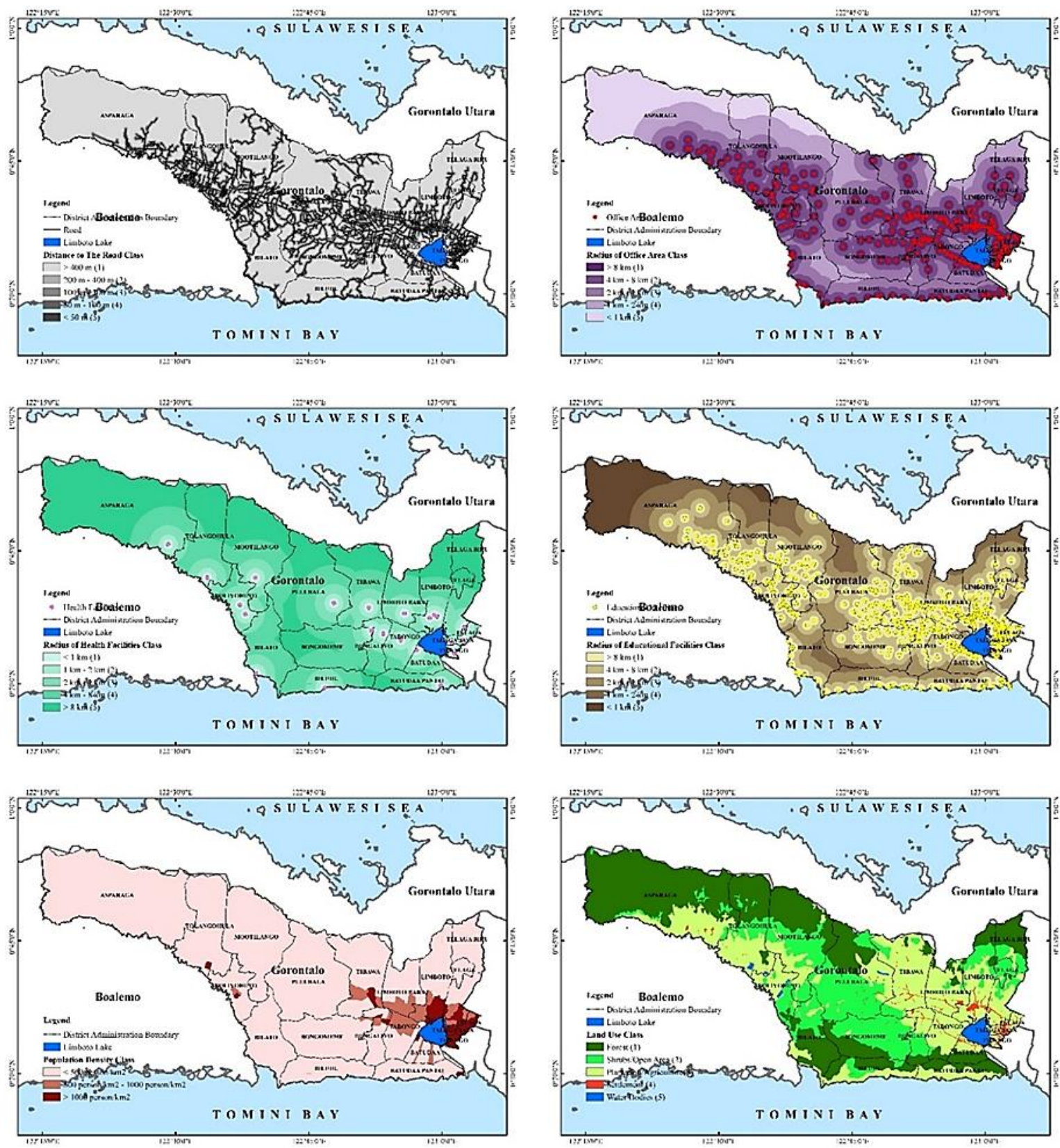

Figure 2. The factors of DHF vulnerability 


\subsection{Data analysis}

Analytical hierarchy process (AHP) is a mathematical solution method which became popular with management in the late 1990s and the early 2000s. Saaty [26], [27] created a multi-criteria decision making technique which gives a systemic approach to evaluate and integrate the effects of many elements with several layers of qualitative and quantitative data dependent or independent. This procedure included a variety of options in the decision and was capable of performing sensitivity analysis on the following criteria and benchmarks. Furthermore, because of the paired comparisons, it simplifies judgments and calculations. In addition, it demonstrates the compatibility and incompatibility decisions that result from multi-criteria decision making. The relative importance of the criteria is scaled from 1 to 9 , with 1 indicating the least important criteria and 9 indicating the most important criteria (Table 1). The AHP procedure is presented in Figure 3 (see Appendix) [26], [27]:

Step 1: Define alternatives

Step 2: Define the problem and criteria

Step 3: Establish Priority amongst criteria using pairwise comparison

Step 4: Check consistency ratio (CR) using (1)

Step 5: Get the relative weights

$$
\mathrm{CR}=\frac{\mathrm{CI}}{\mathrm{RI}}=\frac{\left(\lambda_{\max }-\mathrm{n}\right) / \mathrm{n}-1}{\mathrm{RI}}
$$

In (1) CI is consistency Index while RI is a random index indicating the consistency of a pairwise comparison matrix generated at random (Table 2), $\mathrm{n}$ is number of criteria and $\lambda_{\max }$ is the maximum eigenvalue of the comparison matrix. When the CR value is less than 10\%, the judgment is consistent; when it exceeds $10 \%$, the assessments may need to be revised.

Table 1. The relative importance of the criteria [26], [27]

\begin{tabular}{cll}
\hline Intensity & \multicolumn{1}{c}{ Definition } & \multicolumn{1}{c}{ Explanation } \\
\hline 1 & Equal importance & Two elements contribute equally to the goal \\
3 & Moderate importance & Experience and judgement favor one element slightly more than another \\
5 & Strong importance & Experience and judgement strongly favor one element over another \\
7 & Very strong importance & One element is strongly favored over another, and its dominance is demonstrated in practice \\
9 & Extreme importance & The evidence in favor of one element over another is of the highest order of confirmation \\
$2,4,6,8$ & Can be used to express intermediate values \\
\hline
\end{tabular}

Table 2. Random index (RI) value

\begin{tabular}{ccccccccccc}
\hline $\mathrm{n}$ & 1 & 2 & 3 & 4 & 5 & 6 & 7 & 8 & 9 & 10 \\
\hline $\mathrm{RI}$ & 0.00 & 0.00 & 0.58 & 0.90 & 1.12 & 1.24 & 1.32 & 1.41 & 1.45 & 1.49 \\
\hline
\end{tabular}

\subsection{Ethics approval}

This research does not involve humans in its research, but this research has an ethical license issued by the Kadiri University Research Institute with Registration Number 004/25/V/EC/KEP/UNIK/2021.

\section{RESULTS AND DISCUSSION}

\subsection{Results}

In Table 3, the left-hand criteria are one by one, compared to each top-level criterion, which is more relevant in relation to the goal (determination of DHF vulnerability areas). For calculating the weights for each matrix the own value approach was employed. The synthesis technique, which involved multiplying each ranking by its criterion and sub-criterion priority and adding the resulting weights for each alternative to achieve final priorities, was utilised in achieving the overall priorities. Tables 3 and Table 4 show the weight for each criterion and sub-criterion for determining DHF vulnerability.

Table 3. Pair-wise comparison matrix

\begin{tabular}{ccccccc}
\hline DHF vulnerability class & PD & DR & REF & ROA & RHF & LU \\
\hline PD & 1.00 & 2.00 & 3.00 & 3.00 & 3.00 & 7.00 \\
DR & 0.50 & 1.00 & 4.00 & 4.00 & 0.33 & 5.00 \\
REF & 0.33 & 0.25 & 1.00 & 2.00 & 0.33 & 3.00 \\
ROA & 0.33 & 0.25 & 0.50 & 1.00 & 0.33 & 3.00 \\
RHF & 0.33 & 3.00 & 3.00 & 3.00 & 1.00 & 5.00 \\
LU & 0.14 & 0.20 & 0.33 & 0.33 & 0.20 & 1.00
\end{tabular}

Notes: Population density (PD), distance to the road (DR), radius of educational facilities (REF), radius of office area (ROA), radius of health facilities (RHF), and land use (LU) 
Table 4. Weight of factors

\begin{tabular}{ccccccccc}
\hline DHF vulnerability class & PD & DR & REF & ROA & RHF & LU & Total & Weight vector \\
\hline PD & 0.38 & 0.30 & 0.25 & 0.23 & 0.58 & 0.29 & 2.02 & 0.34 \\
DR & 0.19 & 0.15 & 0.34 & 0.30 & 0.06 & 0.21 & 1.25 & 0.21 \\
REF & 0.13 & 0.04 & 0.08 & 0.15 & 0.06 & 0.13 & 0.59 & 0.10 \\
ROA & 0.13 & 0.04 & 0.04 & 0.08 & 0.06 & 0.13 & 0.47 & 0.08 \\
RHF & 0.13 & 0.45 & 0.25 & 0.23 & 0.19 & 0.21 & 1.45 & 0.24 \\
LU & 0.05 & 0.03 & 0.03 & 0.03 & 0.04 & 0.04 & 0.22 & 0.04 \\
Total & 1.00 & 1.00 & 1.00 & 1.00 & 1.00 & 1.00 & 6.00 & 1.00
\end{tabular}

Notes: Population density (PD), distance to the road (DR), radius of educational facilities (REF), radius of office area (ROA), radius of health facilities (RHF), and land use (LU)

Table 5. Summary of values

\begin{tabular}{cc}
\hline Parameter & Values \\
\hline$\lambda_{\max }$ & 6.49 \\
$\mathrm{n}$ & 6 \\
$\mathrm{RI}$ & 1.24 \\
$\mathrm{CI}$ & 0.1 \\
$\mathrm{CR}$ & 0.079 \\
\hline
\end{tabular}

The DHF vulnerability model was built on the basis of the conditioning factors that have been classed using the AHP method weights. The coefficients and significance have been measured by AHP and are listed in Table 5 or Table 6. Population density had the largest weight (0.34) among the DHF factors, with the most important effects on DHF vulnerability and the lowest weight (0.04) for land use. The DHF vulnerability values were imported to the ArcGIS 10.8 software in order to construct the likelihood map and (2) was utilised for the DHF factors.

\section{$\mathrm{DHFV}=0.34 \mathrm{PD} \times 0.21 \mathrm{DR} \times 0.10 \mathrm{REF} \times 0.08 \mathrm{ROA} \times 0.24 \mathrm{RHF} \times 0.04 \mathrm{LU}$}

where dengue fever vulnerability (DHFV) score, population density (PD) Score, distance to the road (DR) score, radius of educational facilities (REF) score, radius of office area (ROA) score, radius of health facilities (RHF) score, and land use (LU) score.

Table 6. Weight of criteria and sub-criteria

\begin{tabular}{|c|c|c|c|c|c|}
\hline No. & Criteria & Sub-criteria & Criteria weight $(\mathrm{W})$ & Score $(S)$ & WxS \\
\hline \multirow[t]{3}{*}{1} & Population density & $>1,000$ person $/ \mathrm{km}^{2}$ & 0.34 & 3 & 1.012 \\
\hline & & $500-1,000$ person $/ \mathrm{km}^{2}$ & & 2 & 0.675 \\
\hline & & $<500$ person $/ \mathrm{km}^{2}$ & & 1 & 0.337 \\
\hline \multirow[t]{5}{*}{2} & Distance to the road & $<50 \mathrm{~m}$ & 0.21 & 5 & 1.041 \\
\hline & & $50-100 \mathrm{~m}$ & & 4 & 0.833 \\
\hline & & $100-200 \mathrm{~m}$ & & 3 & 0.624 \\
\hline & & $200-400 \mathrm{~m}$ & & 2 & 0.416 \\
\hline & & $>400 \mathrm{~m}$ & & 1 & 0.208 \\
\hline \multirow[t]{5}{*}{3} & Radius of educational facilities & $<1 \mathrm{~km}$ & 0.10 & 5 & 0.489 \\
\hline & & $1-2 \mathrm{~km}$ & & 4 & 0.391 \\
\hline & & $2-4 \mathrm{~km}$ & & 3 & 0.294 \\
\hline & & $4-8 \mathrm{~km}$ & & 2 & 0.196 \\
\hline & & $>8 \mathrm{~km}$ & & 1 & 0.098 \\
\hline \multirow[t]{5}{*}{4} & Radius of office area & $<1 \mathrm{~km}$ & 0.08 & 5 & 0.391 \\
\hline & & $1-2 \mathrm{~km}$ & & 4 & 0.313 \\
\hline & & $2-4 \mathrm{~km}$ & & 3 & 0.235 \\
\hline & & $4-8 \mathrm{~km}$ & & 2 & 0.157 \\
\hline & & $>8 \mathrm{~km}$ & & 1 & 0.078 \\
\hline \multirow[t]{5}{*}{5} & Radius of health facilities & $>8 \mathrm{~km}$ & 0.24 & 5 & 1.211 \\
\hline & & $4-8 \mathrm{~km}$ & & 4 & 0.969 \\
\hline & & $2-4 \mathrm{~km}$ & & 3 & 0.727 \\
\hline & & $1-2 \mathrm{~km}$ & & 2 & 0.484 \\
\hline & & $<1 \mathrm{~km}$ & & 1 & 0.242 \\
\hline \multirow[t]{5}{*}{6} & Land use & Water bodies & 0.04 & 5 & 1.211 \\
\hline & & Settlement & & 4 & 0.969 \\
\hline & & Plantation/Agriculture & & 3 & 0.727 \\
\hline & & Shrubs/Open area & & 2 & 0.484 \\
\hline & & Forest & & 1 & 0.242 \\
\hline
\end{tabular}


As shown in Figure 4, the DHF vulnerability map produced by combining population density, distance to the road, radius of health facilities, radius of educational facilities, radius of office area, and land use highlights five classes (very low to very high). In the next stage, a probability DHF vulnerability of $<2.036$ to $>4.525$ was computed in (2). In the presence of any set of DHF factors, this index shows the projected DHF vulnerability for each grid. DHF The vulnerability map was developed by methods of the popular literature technique by splitting the vulnerability map into distinct groups. The DHF vulnerability map range was divided into five groups of very low (<2.036), low (2.036-2.866), moderate $(2.866-3.696)$, high (3.696-4.525), and very high $(>4.525)$ by a quantile approach. Figure 4 shows the DHF vulnerability map created using the ensemble DHFV model (2).

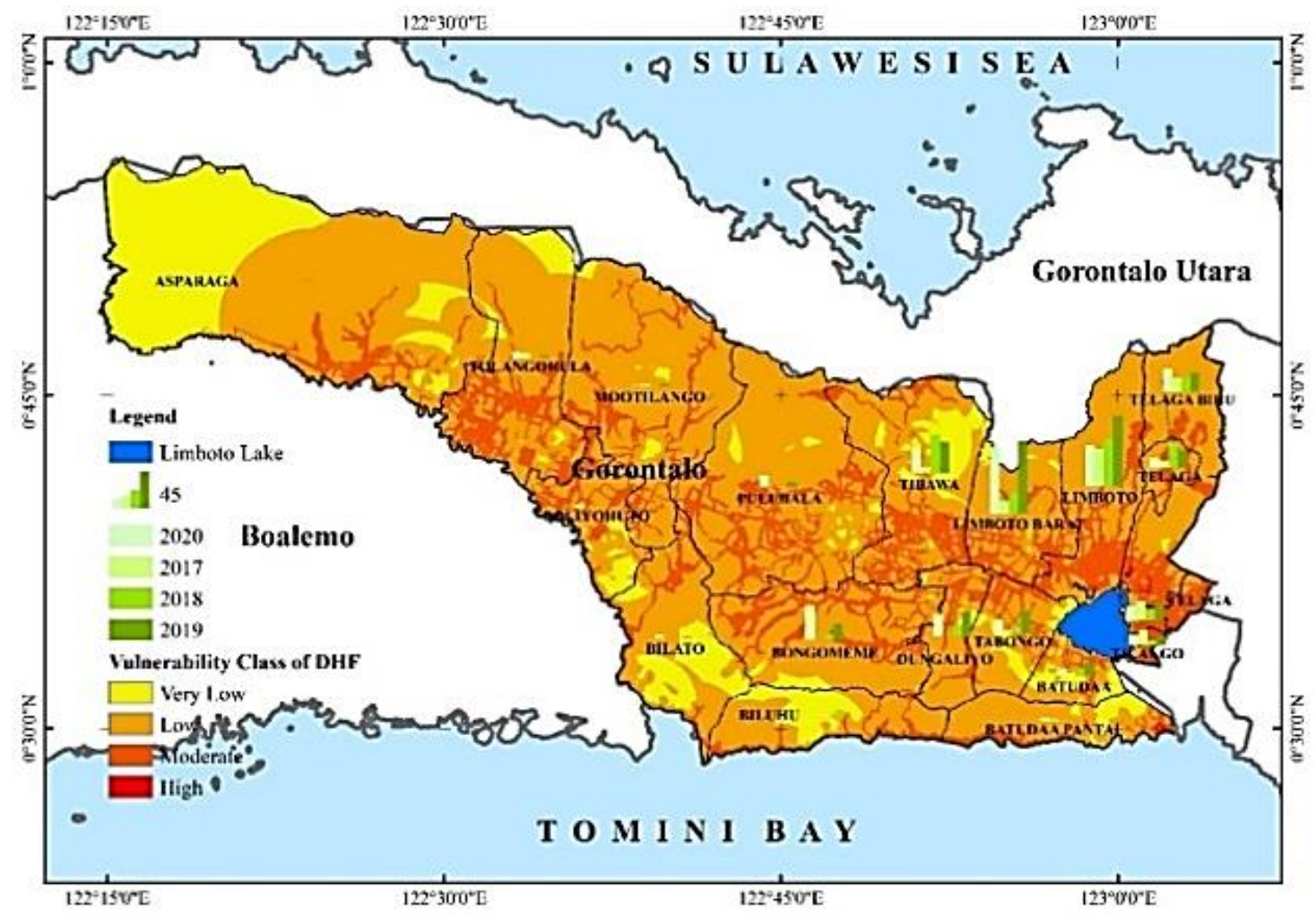

Figure 4. Distribution of DHF vulnerability class

The very low and low classes account for $16.06 \%$ and $65.08 \%$ of the Gorontalo Regency, respectively (Table 7). It is primarily areas with forest and plantation, with a lower population density. The proportions of areas covered by the moderate and high classes of vulnerability are $17.71 \%$ and $0.08 \%$, respectively. According to the analysis, all of these areas of moderate and high vulnerability are dominated by their proximity to public facilities and roads, distance from health facilities, high population density, and settlement within the Gorontalo Regency.

\begin{tabular}{cccc}
\multicolumn{4}{c}{ Table 7. Distribution of DHF vulnerability class } \\
\hline DHF vulnerability class & Range weight & $\begin{array}{c}\text { Area } \\
\text { (Ha) }\end{array}$ & $\begin{array}{c}\% \\
\text { Area }\end{array}$ \\
\hline Very low & $<2.036$ & $34,425.6$ & 16.06 \\
Low & $2.036-2.866$ & $139,493.5$ & 65.08 \\
Moderate & $2.866-3.696$ & $37,963.8$ & 17.71 \\
High & $3.696-4.525$ & 163.5 & 0.08 \\
Very high & $>4.525$ & 0.0 & 0 \\
Limboto lake & & $2,295.5$ & 1.07 \\
Total & & $214,341.9$ & 100 \\
\hline
\end{tabular}




\subsection{Discussion}

Environmental factors are thought to play a role in the transmission and spread of DHF, according to a number of studies. It is possible that environmental elements will have an impact on the transmission pattern of DHF, either directly or indirectly. A direct impact can be characterised as a change in environmental variables that has an impact on the trend of DHF transmission and the pattern of DHF transmission. A few examples of environmental elements that have an indirect impact on the trend of DHF transmission and distribution are human population dynamics and their effects on exposure vulnerability, as well as other landscape features [13]. Using AHP to combine different variables, the overall model of DHF vulnerability in Gorontalo Regency reveals that the vulnerability area is primarily confined to places with high population density, which is consistent with the findings of the previous study. This finding is consistent with the findings of several studies, which found that DHF risk cases increased in areas with a high population density [1], [28]-[30]. The higher the population of an area will be the greater the potential for female mosquitoes to fly and bite between humans and each other. They live for an average of 8-15 days and can fly 30-50 m per day, covering a distance of 240-600 $\mathrm{m}$ in their lifetime [17]. The Aedes aegypti mosquito is found in urban areas and breeds mostly in containers that have been constructed by humans.

When it comes to DHF and other diseases carried by the Aedes aegypti mosquito, the closeness of mosquito vector breeding sites to human settlement is a significant vulnerability factor. The main approach to regulating or preventing DHF virus transmission is now the control or eradication of mosquito vectors (vectors) [31]. Therefore, the variables related to the potential location for mosquitoes to breed are public facilities which of course have containers (i.e. road, educational facilities, and office area). Wanti et al. [32], [33] was concluded that the container conditions related to the incidence of DHF. The influence of population density variables, distance to highways, educational facilities radius, office area radius, and land use on the spread of dengue fever in two ways, namely prevention of mosquito breeding such as: i) preventing mosquitos from accessing egg-laying habitats through environmental management and modification; ii) removing artificial man-made habitats that can hold water and properly disposing of solid waste; iii) weekly covering, emptying, and cleaning of domestic water storage containers; and iv) applying appropriate insecticides to outdoor water storage containers and personal protection from mosquito bite (i.e. window screens, repellents, insecticide-treated materials, coils, and vaporizers). Due to the fact that the principal mosquito vectors bite continuously throughout the day, these precautions must be performed both inside and outside the home (e.g., at work/school). It is recommended that people should wear clothes that minimises the exposure of your skin to mosquitoes [31].

The presence of distant health facilities has a significant impact on this study, accounting for $24 \%$ of the total. There are three approaches to overcoming this factor. The first is community engagement (i.e., educating people about the dangers of mosquito-borne diseases, engaging people in order to increase participation and mobilisation for long-term vector control), the second is reactive vector control (i.e., health authorities may use emergency vector control measures such as space spraying insecticides during outbreaks), and proactive vector control such as: i) to determine the effectiveness of control interventions, active monitoring and surveillance of vector abundance and species composition should be carried out; and ii) active screening of sentinel mosquito collections will be used to track the prevalence of virus in the mosquito population in the future) [31]. In recent years, developments in geographic information systems (GIS) technology have made it possible to anticipate DHF outbreaks on a local and regional scale with greater accuracy than ever before. A greater knowledge of the relationship between DHF spatial and temporal distributions has resulted, as has an increased interest in epidemic prediction modelling and other related fields.

\section{CONCLUSION}

Spatial temporal modelling techniques, such as GIS-AHP, can be used to display and model the spatial relationship between cases and disease. In part, this is due to the powerful application of geographic information systems (GIS) technology to visualise and understand temporal and spatial distributions based on ecological determinants. Spatial temporal modelling can aid in understanding the distribution of dengue outbreaks in space and time. AHP assists the decision maker in making the correct decision by indicating the importance of the decision, and inconsistency will appear if the decision is incorrect. As demonstrated by the GIS-AHP utilised in this study, all selected decision criteria with various weights satisfy the Consistency Ratio. As a result, they are considered acceptable and consistent for DHF vulnerability mapping in Gorontalo Regency.

There are no medically approved therapies for DHF at the present time. The only way to treat this condition is to discover an appropriate breeding location, such as a vector, and destroy it. Therefore, the current research focuses on some of the closely connected environmental elements that are responsible for DHF outbreaks, as well as GIS-based spatial analysis for the purpose of identifying vulnerabilit zones. 
According to the findings, the Gorontalo Regency dominated low-class vulnerability in general. A technique similar to the one utilised in the current study might be used to assess transmissible disease vulnerability zonation, which would aid in refining surveillance stratagems for DHF and other vector-borne diseases in order to stimulate prevention and control actions.

\section{ACKNOWLEDGEMENTS}

The authors would like to thank all of the organizations mentioned in the paper for providing the necessary data for the study, as well as the Ministry of Research and Higher Education of the Republic of Indonesia for providing financial support in the form of research funding.

\section{REFERENCES}

[1] D. S. S. Rejeki, N. Nurhayati, and B. Aji, "A spatiotemporal analysis of dengue hemorrhagic fever in Banyumas, Indonesia," International Journal of Public Health Science (IJPHS), vol. 10, no. 2, pp. 231-240, 2021, doi: 10.11591/ijphs.v10i2.20713.

[2] J. J. Waggoner et al., "Viremia and clinical presentation in nicaraguan patients infected with zika virus, chikungunya virus, and dengue virus," Clinical infectious diseases : an official publication of the Infectious Diseases Society of America, vol. 63, no. 12, pp. 1584-1590, 2016, doi: 10.1093/cid/ciw589.

[3] S. Bhatt et al., "The global distribution and burden of dengue," Nature, vol. 496, no. 7446, pp. 504-507, 2013, doi: 10.1038/nature12060.

[4] O. J. Brady et al., "Refining the global spatial limits of dengue virus transmission by evidence-based consensus," PLoS Neglected Tropical Diseases, vol. 6, no. 8, pp. 1-15, 2012, doi: 10.1371/journal.pntd.0001760.

[5] A. Murad, "Using GIS for determining variations in health access in Jeddah City, Saudi Arabia," ISPRS International Journal of Geo-Information, vol. 7, no. 7, p. 254, Jun. 2018, doi: 10.3390/ijgi7070254.

[6] J. Y. Kim, S. J. Eun, and D. K. Park, "Malaria vulnerability map mobile system development using GIS-Based Decision-making technique," Mobile Information Systems, vol. 2018, pp. 1-10, 2018, doi: 10.1155/2018/8436210.

[7] I. Franch-Pardo, B. M. Napoletano, F. Rosete-Verges, and L. Billa, "Spatial analysis and GIS in the study of COVID-19. A review," Science of the Total Environment, vol. 739, pp. 1-10, 2020, doi: 10.1016/j.scitotenv.2020.140033.

[8] S. Ajim Ali, A. Ahmad, S. A. Ali, and A. Ahmad, "Using analytic hierarchy process with GIS for dengue risk mapping in kolkata municipal corporation, West Bengal, India," Spatial Information Research, vol. 26, no. 4, pp. 449-469, Aug. 2018, doi: $10.1007 / \mathrm{s} 41324-018-0187-\mathrm{x}$

[9] S. Sulistyawati, "Measuring the dengue risk area using geographic information system: a review," Insights in Public Health Journal, vol. 1, no. 1, p. 36, 2020, doi: 10.20884/1.iphj.2020.1.1.3012.

[10] R. Pakaya, "Spatial analysis and environmental factors associated against case of dengue hemorrhagic fever (DHF) in Limboto District, Gorontalo," in Gorontalo University, 2010, pp. 45-55.

[11] S. Saran, P. Singh, V. Kumar, and P. Chauhan, "Review of geospatial technology for infectious disease surveillance: use case on COVID-19," Journal of the Indian Society of Remote Sensing, vol. 48, no. 8, pp. 1121-1138, Aug. 2020, doi: 10.1007/s12524020-01140-5.

[12] B. Bhatt and J. P. Joshi, "Analytical hierarchy process modeling for malaria risk zones in vadodara district, Gujarat," International Archives of the Photogrammetry, Remote Sensing and Spatial Information Sciences - ISPRS Archives, vol. XL-8, no. 1, pp. 171-176, 2014, doi: 10.5194/isprsarchives-XL-8-171-2014.

[13] N. C. Dom, A. H. Ahmad, Z. A. Latif, and R. Ismail, "Application of geographical information system-based analytical hierarchy process as a tool for dengue risk assessment," Asian Pacific Journal of Tropical Disease, vol. 6, no. 12, pp. 928-935, 2016, doi: $10.1016 / \mathrm{S} 2222-1808(16) 61158-1$.

[14] H. A. Rakotoarison et al., "Remote sensing and multi-criteria evaluation for malaria risk mapping to support indoor residual spraying prioritization in the central highlands of Madagascar," Remote Sensing, vol. 12, no. 10, pp. 1-22, 2020, doi: $10.3390 / \mathrm{rs} 12101585$.

[15] X. Li et al., "Application of the analytic hierarchy approach to the risk assessment of Zika virus disease transmission in Guangdong Province, China," BMC Infectious Diseases, vol. 17, no. 1, pp. 1-9, 2017, doi: 10.1186/s12879-016-2170-2

[16] N. H. Schafrick, M. O. Milbrath, V. J. Berrocal, M. L. Wilson, and J. N. S. Eisenberg, "Spatial clustering of Aedes aegypti related to breeding container characteristics in coastal Ecuador: Implications for dengue control," American Journal of Tropical Medicine and Hygiene, vol. 89, no. 4, pp. 758-765, 2013, doi: 10.4269/ajtmh.12-0485.

[17] A. Bohra and H. Andrianasolo, "Application of GIS in modeling of dengue risk based on sociocultural data: Case of Jalore, Rajasthan, India,” Dengue Bulletin, vol. 25, pp. 92-102, 2001.

[18] W. P. Schmidt et al., "Population density, water supply, and the risk of dengue fever in vietnam: Cohort study and spatial analysis," PLoS Medicine, vol. 8, no. 8, pp. 1-10, 2011, doi: 10.1371/journal.pmed.1001082.

[19] A. Kusairi and R. Yulia, "Mapping of dengue fever distribution based on indonesian national standard cartography rules as an prevention indicator of outbreaks," Jurnal Pendidikan IPA Indonesia, vol. 9, no. 1, pp. 91-96, Mar. 2020, doi: 10.15294/jpii.v9i1.21811.

[20] C. D. Chen, H. L. Lee, S. P. Stella-Wong, K. W. Lau, and M. Sofian-Azirun, "Container survey of mosquito breeding sites in a university campus in Kuala Lumpur, Malaysia," Dengue Bulletin, vol. 33, no. 1, pp. 187-193, 2009.

[21] R. S. Mahabir, D. W. Severson, and D. D. Chadee, "Impact of road networks on the distribution of dengue fever cases in Trinidad, West Indies," Acta Tropica, vol. 123, no. 3, pp. 178-183, Sep. 2012, doi: 10.1016/j.actatropica.2012.05.001.

[22] M. A. F. M. A. F. Regilme, T. M. T. M. Carvajal, A. C. Honnen, D. M. D. M. Amalin, and K. Watanabeid, "The influence of roads on the fine-scale population genetic structure of the dengue vector Aedes aegypti (Linnaeus)," PLoS Neglected Tropical Diseases, vol. 15, no. 2, pp. 1-14, Feb. 2021, doi: 10.1371/journal.pntd.0009139.

[23] H. Harapan, A. Michie, M. Mudatsir, R. T. Sasmono, and A. Imrie, "Epidemiology of dengue hemorrhagic fever in Indonesia: Analysis of five decades data from the National Disease Surveillance," BMC Research Notes, vol. 12, no. 1, pp. 4-9, 2019, doi: 10.1186/s13104-019-4379-9.

[24] Y. L. Cheong, P. J. Leitão, and T. Lakes, “Assessment of land use factors associated with dengue cases in Malaysia using boosted

Int J Public Health Sci, Vol. 11, No. 1, March 2022: 138-148 
regression trees," Spatial and Spatio-temporal Epidemiology, vol. 10, pp. 75-84, 2014, doi: 10.1016/j.sste.2014.05.002.

[25] R. V. Araujo et al., "São Paulo urban heat islands have a higher incidence of dengue than other urban areas," Brazilian Journal of Infectious Diseases, vol. 19, no. 2, pp. 146-155, 2015, doi: 10.1016/j.bjid.2014.10.004.

[26] T. L. Saaty, "The analytic hierarchy process," New York: McGraw Hill. International, 1980.

[27] T. L. Saaty, "Decision making with the analytic hierarchy process," International Journal Services Sciences, vol. 1, no. 1, pp. 8398, 2008, doi: 10.1504/IJSSCI.2008.017590.

[28] Wanti et al., "Dengue hemorrhagic fever and house conditions in Kupang City, East Nusa Tenggara Province," Kesmas, vol. 13, no. 4, pp. 177-182, 2019, doi: 10.21109/kesmas.v13i4.2701.

[29] H. Fuadzy et al., "Risk factors associated with dengue incidence in Bandung, Indonesia: a household based case-control study," Health Science Journal of Indonesia, vol. 11, no. 1, pp. 45-51, Jun. 2020, doi: 10.22435/hsji.v11i1.3150.

[30] A. Gulácsi and F. Kovács, "Drought monitoring with spectral indices calculated from modis satellite images In Hungary," Journal of Environmental Geography, vol. 8, no. 3-4, pp. 11-20, 2015, doi: 10.1515/jengeo-2015-0008.

[31] WHO, "Managing Epidemics: Key Facts About Major Deadly Diseases." Geneva, 2018. http://apps.who.int/iris/handle/10665/272442?searchaccesresult=true\&query=Managing+Epidemics $\% 2 \mathrm{C}+$ Key+facts+about+major+deadly+diseases\&scope=\&rpp=10\&sort_by=score \&order=desc (accessed Jul 30, 2021).

[32] W. Wanti, R. Yudhastuti, H. B. Notobroto, S. Subekti, A. Agustina, and C. Ekawati, "Container characteristics and dengue hemorrhagic fever incidence," International Journal of Public Health Science (IJPHS), vol. 8, no. 3, pp. 314-319, 2019, doi: 10.11591/ijphs.v8i3.18066.

[33] W. Wanti, R. Yudhastuti, S. Yotopranoto, H. B. Notobroto, S. Subekti, and S. R. Umniati, "Container positivity and larva distribution based on the container characteristics," International Journal of Public Health Science (IJPHS), vol. 6, no. 3, p. 237, 2017, doi: 10.11591/ijphs.v6i3.9290.

\section{BIOGRAPHIES OF AUTHORS}

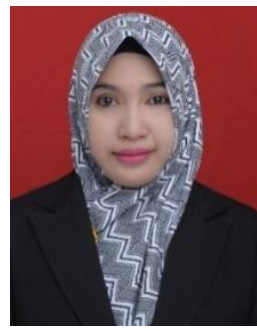

Ririn Pakaya (D) 8 SC P completed his Masters in Public Health at the Faculty of Medicine, Universitas Gadjah Mada. Working as a Lecturer in the Public Health Sciences Study Program. As a Lecturer and Researcher, carrying out research and development tasks in the field of Environmental Health. Scientific works published in Journals including: Spatial Analysis and Environmental Factors Associated Against Case of dengue hemorrhagic fever (DHF) in Limboto District, Gorontalo (2017), Spatial-Temporal Analysis Incidence Of Dengue Hemorrhagic Fever (Dhf) Against Weather Variable In Limboto And Telaga Biru District, Gorontalo Regency Year 2012-2015(2017), The Influence of Spatial Distribution of Social Environmental Factors on the Incidence of Dengue Hemorrhagic Fever (DHF) in Limboto District (2018), Factors related to Pulmonary Tuberculosis Incident in Public Health Center of Limboto Year (2020), Spatial Distribution of Pulmonary Tuberculosis BTA Positive Associated with Weather Factors in Gorontalo City 2016-2018 (2021). Her team has received one award recognizing the excellence and innovation of the work: Best presenter award, International Seminar in The 1st International Seminar on Developing Country, Makassar 2019. She can be contacted at email: ririn.pakaya@mail.ugm.ac.id.

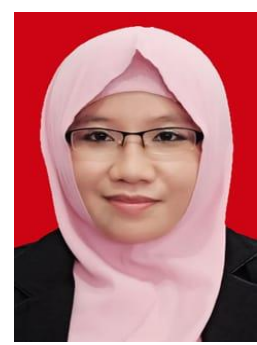

Yanti Hz. Hano (iD) SC $\mathrm{P}$ earned her magister degree in Public Health Faculty in Universitas Samratulangi Manado. Her Current research focus on public health administration. Evaluation of The Implementation of The Elderly Posyandu Program in the work area of The Bongomeme Health Center, Gorontalo Regency. She can be contacted at email: hanoyantiakk@gmail.com.

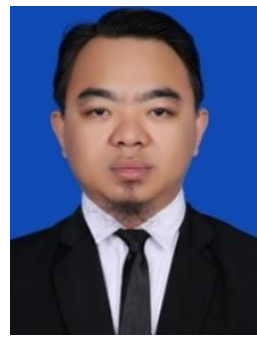

Muhammad Ramdhan Olii (iD S SC P earned his Doctoral degree in Civil Engineering Doctoral Program-Faculty of Engineering Universitas Gadjah Mada Yogyakarta. His current research focuses on geographic information system in hydrology engineering, water resources development, disaster, land conservation and environment. His team has received many awards recognising the excellence and innovation of the work: a) Best presenter award, National Seminar in Institut Teknologi Bandung, Bandung, 2015, b) Best presenter award, Indonesian Association of Hydraulic Engineers Seminar Internaional, Bali, 2016, c) Best presenter award, National Seminar in Institut Teknologi Bandung, Bandung, 2017, and d) Best presenter award, The 1st International Conference on Innovation in Science, Health, and Technology (ICISHT), Gorontalo, 2020. His team has received several research grant from the Ministry of Research and Higher Education of the Republic of Indonesia: Doctoral Research Grant, 2016, Novice Lecturer Research Grant, 2018, Research Quality Improvement and Publications of Lecturers 2018 and 2019, and College Excellence Basic Research Grant 2019-2020. He can be contacted at email: kakaramdhanolii@gmail.com. 


\section{APPENDIX}

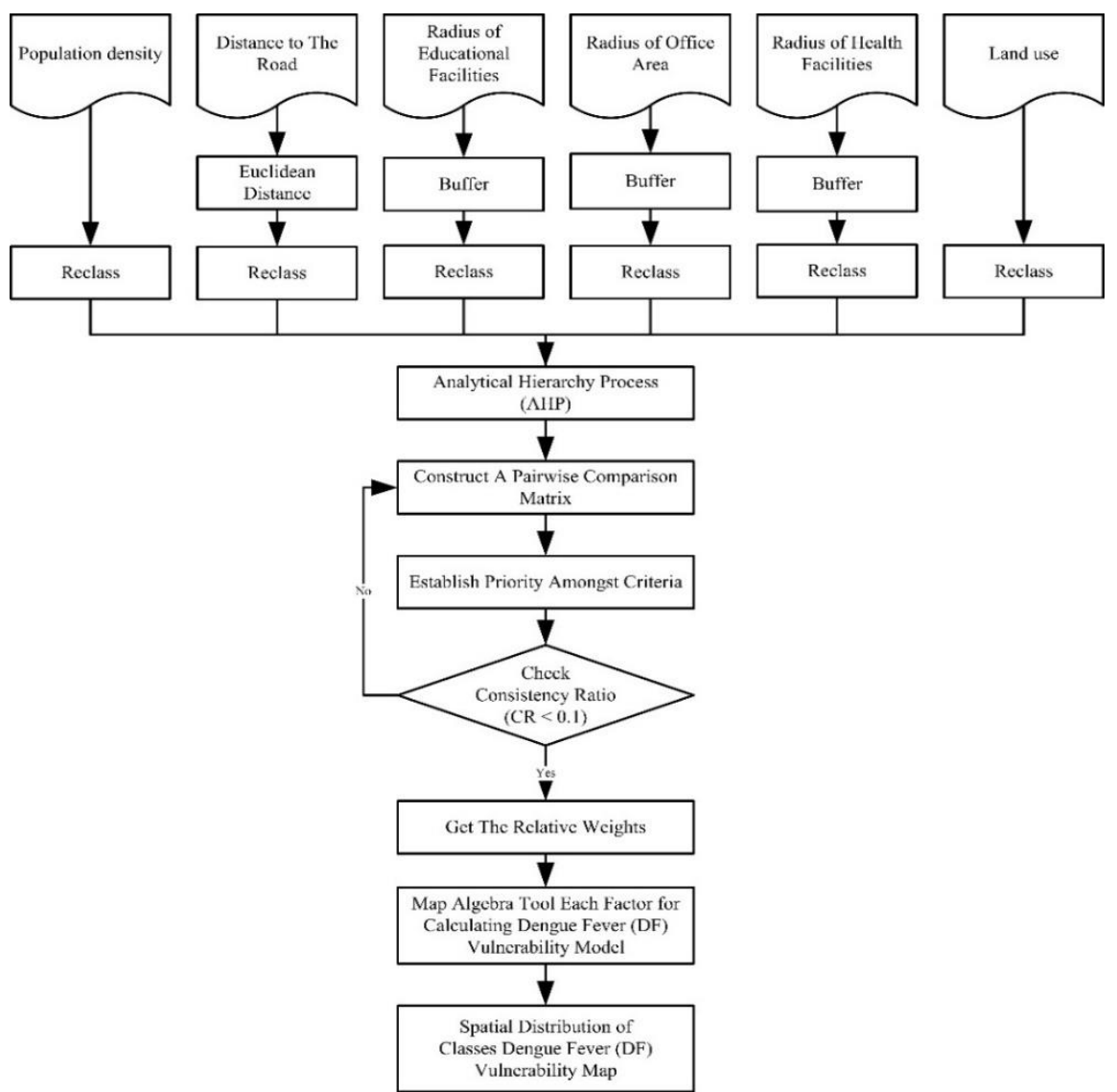

Figure 3. Flow chart of AHP procedure 